

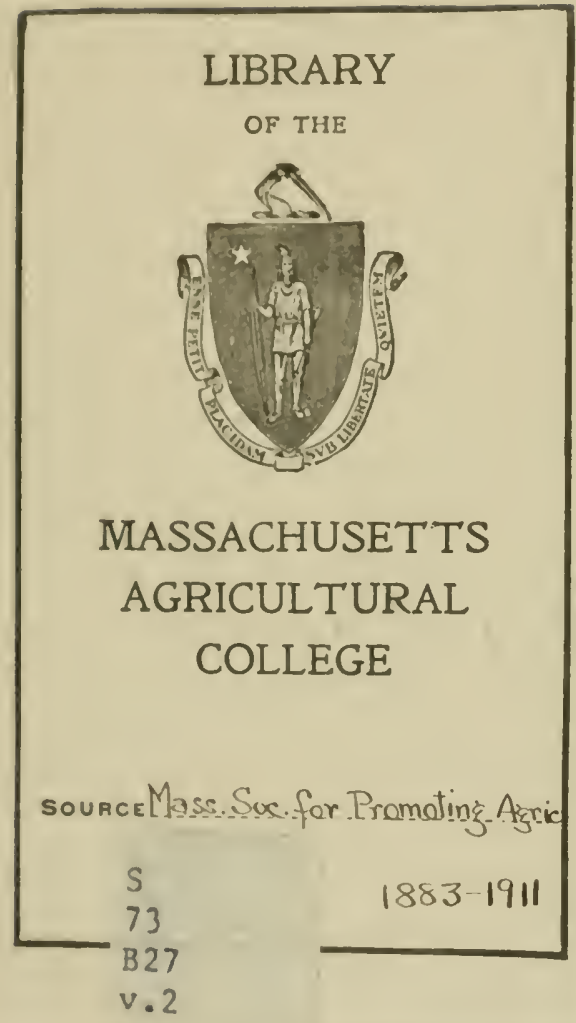






\section{Protection of the Forests of the}

\section{Commoniwealth.}

The neressity for a law more conurrohensive than can now be found upon the Statute Borks of Massachusetts for the protection of forests against fire, has long been fult by all persons interested in forest preperty. The dimage inflicted erery year by forest fires in this state is very large. 'The damage is not confinerl to the actual destruction of trees. Forest fires dustroy the forest, the fertility of the soil, and consequently its calpacity to reproduce the forest grw wh thus distroyed. 'The gradual deterioration in the composition of the forest, the result of fire, represents a more permanent and serions loss to the ritate than the lestruction of a single forest crop. The frequent occurence of forest fires destroys confidence in the value of forest property. A community in which no real effort is made to prevent or control forest fires, laas little encomagement to improve or extend its forests. The fear of forest tires makes iwrestments in forest property insecure and molesirable; it prevents forest planting. and eauses the premature cntting of immature forests. Any attempt to improve the forests of the State is uscless mitil they can be secured greater immunity from tire.

The law already sulliciently provides for the protection of the forest against fires originating in malice and wanton recklessiçss, by the following sections: 


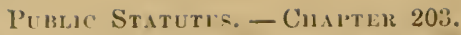

Sietıox 5. Whoever willfully and malieiously burns or otherwise destroys or injures a pile or pircel of wood *** or any standing tree *** of another shall be punished by imprisonment in the State prison not cxceeling five years, or by fine not exceeding five hundred dollars and imprisomment in the jail not excecding one year.

\section{S82. CuAMTER 163.}

SLстіох 1. Whoever wantonly and recklessly sets fire to any materials which causes the destruction or injury of any growing or standing wood of another shall be punished by fine not exceeding one hundred dollars, or by inpurisonment in jail not exceeding six montlys.

Forest fires rarely originate in malice but in earelessness, and provision is needed for the prevention and punishment of such carclessness.

A Committee acting under authority from the Massachusetts Horticultural Society, and after having heard the opinion of many persons interested in the matter, have determined to present the accompanying bill for legislative action.

Tre invite the co-operation of all interested in the agricultural prosperity of Massachusetts in securing its passage.

It must not be forgotten that legislation in advance of public sentinent camnot accomplish any rery marked results, and unless the commercial and climatic value of the forest to the commmity is appreciated, the mere passage of a law will not greatly decrease the number of fires. The forest will only find perfect protection in general appreciation.

\section{CIIARLES S. SARGENT,}

Chairman.

Frincis II. Appleton,

Secretary of Committee. 



